\title{
Pemberian Pupuk Alam Terhadap Serapan Nitrogen dan Hasil Sawi di Alfisols
}

\author{
Sumarno1), Hery Widjianto1), Rosinta Kusuma W21
}

\begin{abstract}
This research conducted to determine the exact formula and dosage to increase the uptake of $\mathrm{N}$ and increase yield of green mustard. The research conducted at Jumantono dryland research center, Karanganyar and Laboratory of Chemistry and Soil Fertility, Faculty of Agriculture UNS Solo. This study uses a randomized complete block design (RCBD) using 5 formulas as the first treatment factor and 4 dosages as second treatment factor. The data analysis used $\mathrm{F}$ test level of $5 \%$ and if significant continued by DMRT (Duncan Multiple Range Test) level of $5 \%$. The variables of this research were weight of wet stover, weight of dry stover, $\mathrm{N}$ total and absorption of $\mathrm{N}$. The results showed that the combination of dosage and formula of natural fertilizers can increase $\mathrm{N}$ uptake and yield of mustard on the ground Alfisols.
\end{abstract}

Keywords : natural fertilizer, $\mathrm{N}$ uptake, green mustard

\section{PENDAHULUAN}

Berkaitan dengan tuntutan pupuk berwawasan lingkungan dan upaya menurunkan ketergantungan pupuk kimia, maka pengembangan dan penggunaan pupuk yang berasal dari alam merupakan teknologi alternatif yang dapat dijangkau. Teknologi budidaya yang diterapkan harus mengarah kepada penggunaan input-input produksi yang lebih aman terhadap kesehatan dan lingkungan. Pemberian pupuk organik, pupuk bio dan pupuk alam memberikan respon yang positif terhadap pertumbuhan dan produksi tanaman. Menurut Ruhnayat (2010) Pupuk alam adalah pupuk yang bersumber dari hasil pertambangan yang sudah tersedia di alam (fosfat alam, zeolit, kapur dan sebagainya.

Produksi sawi yang tinggi dan berkualitas diperoleh dengan teknik budidaya yang baik, diantaranya melalui pemupukan yang benar, tepat dan sesuai kebutuhan, dan hanya sekitar $0,3 \%$ yang melaksanakan sistem pertanian organik. Sawi sebagai sayuran daun akan terpacu pertumbuhannya jika tanah banyak mengandung bahan organik dengan kelembaban yang cukup.

Secara umum tanah Alfisols Jumantono mempunyai kesuburan yang rendah sampai sedang, ini ditunjukkan dari kandungan $\mathrm{N}$

1)Lecturer Staff of Study Program of Agrotechnology, Faculty of Agriculture, Sebelas Maret University (UNS) on Surakarta.

2)Undergraduate Student of Study Program of Agrotechnology, Faculty of Agriculture, Sebelas Maret University (UNS) on Surakarta.

Contact Author: rosintarsy@gmail.com tersedia $\left(\mathrm{NH}^{4+}\right.$ dan $\left.\mathrm{NO}^{3-}\right), \mathrm{P}$ tersedia $5.13 \mathrm{ppm}$, dan $\mathrm{K}$ tertukar $0.26 \mathrm{me} \%$ rendah, hal ini dikarenakan tanah ini merupakan tanah yang sudah lanjut sehingga terjadi pencucian hara yang mengakibatkan kandungan haranya rendah, meskipun kandungan C-Organiknya tinggi 3.89\% (dikarenakan adanya pengelolaan sehingga kandungan C-Organik ditanah Alfisols ini tinggi). Kadar lengas tanah Alfisols 4,86\%, sedangkan proses nitrifikasi berlangsung optimal pada tanah-tanah dengan kadar lengas kapasitas lapangan $60 \%$ dari ruang pori yang terisi air (Purwanto 2007).

\section{METODE PENELITIAN}

Penelitian ini dilaksanakan pada bulan Juli 2015 sampai Januari 2016 di Laboratorium Kimia dan Kesuburan Tanah, Laboratorium Fisika dan Konservasi Tanah Fakultas Pertanian Universitas Sebelas Maret Surakarta. Bahan yang digunakan adalah tanah Alfisols, benih sawi, kotoran puyuh kering, azzola kering, fosfat alam, arang batok kelapa, abu batok dan sabut, dolomit, belerang erlemnenter, feldspar, sample tanah Ctka ǿ 0,5 $\mathrm{mm}$, Ctka ǿ $2 \mathrm{~mm}$, sampel jaringan, ammonium scetat $1 \mathrm{~N}$, alkohol $95 \%, \mathrm{NaCl} 10 \%, \mathrm{NaOH}, \mathrm{HCl}$ $0,1 \mathrm{~N}$, asam borat $2 \%$, indikator campuran, aquadest, butir $\mathrm{Zn}, \mathrm{K}_{2} \mathrm{Cr}_{2} \mathrm{O}_{7}$, asam sulfat pekat, $\mathrm{FeSO}_{4}$, indikator DPA, $\mathrm{LiCl}_{2} 0,05 \mathrm{~N}, \mathrm{HClO}_{4}$, $\mathrm{HNO}_{3}$, kertas whatman. Alat yang digunakan polibag, cangkul, cetok, mesin penggiling pupuk, karung, grinder, tabung reaksi, timbangan analitik, tabung reaksi, pemanas, erlemeyer, pipet ukur, labu destilasi, destilator, gelas ukur.

Rancangan penelitian yang digunakan adalah Rancangan Acak Kelompok Lengkap (RAKL), dengan menggunakan 2 faktor yaitu formula pupuk dan dosis pupuk. Formula pupuk 
yang terdiri atas 5 taraf yaitu Formula 1 yaitu kotoran puyuh $50 \%$, fosfat alam $20 \%$, abu batok dan sabut kelapa $18 \%$, dolomit $6 \%$, belerang erlenmentar $1 \%$, dan feldspar 5\%; Formula 2 yaitu kotoran puyuh $60 \%$, fosfat alam $20 \%$, abu batok dan sabut kelapa 14\%, dolomit 5,5\%, belerang erlenmentar 0,5\%; Formula 3 yaitu kotoran puyuh $60 \%$, azolla $20 \%$, fosfat alam $16 \%$, abu batok dan sabut kelapa $23 \%$, dolomit $10 \%$, belerang erlenmentar 1\%; Formula 4 yaitu kotoran puyuh $26 \%$, azolla $25 \%$, fosfat alam $20 \%$, abu batok dan sabut kelapa $18 \%$, dolomit $10 \%$, belerang erlenmentar 1\%; Formula 5 yaitu kotoran puyuh $30 \%$, azolla $20 \%$, fosfat alam $15,5 \%$, abu batok dan sabut kelapa $19 \%$, dolomit $10 \%$, belerang erlenmentar $0,5 \%$, dan feldspar $5 \%$. Faktor yang kedua adalah dosis pupuk yang terdiri 4 taraf yaitu D1 $=2500 \mathrm{~kg} / \mathrm{Ha}, \mathrm{D} 2=5000$ $\mathrm{kg} / \mathrm{Ha}, \mathrm{D} 3=7500 \mathrm{~kg} / \mathrm{Ha}$, dan D4 = $10000 \mathrm{~kg} / \mathrm{H}$. Masing-masing kombinasi perlakuan diulang 3 kali. Pengamatan peubah meliputi berat segar brangkasan, berat kering brangkasan, $\mathrm{N}$ total tanah, dan serapan N. Data hasil pengamatan diuji dengan menggunakan uji $\mathrm{F}$ taraf $5 \%$.

\section{Bahan pupuk}

Bahan pupuk yang digunakan dalam penelitian ini berupa azolla kering, kotoran puyuh yang sudah kering dan dihaluskan, abu sabut dan batok kelapa, fosfat alam, feldspar, dan dolomit.

Tabel 1. Hasil analisis bahan pupuk alam
Apabila signifikan maka dilanjutkan dengan uji Duncan Multiple Range Test (DMRT) taraf 5\%.

\section{HASIL DAN PEMBAHASAN}

\section{Kondisi umum lokasi penelitian}

Lahan penelitian yang digunakan merupakan lahan kering yang berlokasi di Desa Sukosari, Jumantono, Karanganyar dan merupakan jenis tanah alfisol. Lahan penelitian terletak di ketinggian $182 \mathrm{mdpl}$, pada $7^{\circ} 37^{\prime} 42,1^{\prime \prime}$ LU dan $110^{\circ} 57^{\prime} 6,9^{\prime}$ LS. Lahan penelitian dirancang homogen dengan cara pemasangan rumah plastik, dan tanaman yang ditanam diletakkan didalam polibag.

Berdasarkan hasil analisis tanah awal dapat dijelaskan bahwa lahan penelitian memiliki kandungan unsur hara yang sedang yaitu $\mathrm{pH}$ tanah 5,75 termasuk kategori agak masam; KTK sedang $21,75 \mathrm{cmol} \%$; $N$ total sedang $0,22 \%$; $P$ tersedia rendah $15 \mathrm{mg} / 100 \mathrm{gr} ; \mathrm{K}$ tersedia rendah $16 \mathrm{mg} / 100 \mathrm{gr}$; dan bahan organik sedang $2,60 \%$. Kondisi tanah tersebut akan mempengaruhi ketersediaan unsur hara di dalam tanah sehingga untuk mendukung produktivitas tanah perlu diberi masukan dalam pengelolaanya.

Pembuatan bahan pupuk alam ditujukan untuk mengurangi penggunaan pupuk an-organik. Berdasarkan bahan-bahan pupuk diatas, dilakukan analisis untuk mengetahui unsur hara utama yang terkandung dari masing-masing bahan pupuk.

\begin{tabular}{|c|c|c|c|c|c|c|c|c|}
\hline No & Bahan Pupuk & $\begin{array}{c}\begin{array}{c}\text { C-org } \\
(\%)\end{array} \\
\end{array}$ & $\begin{array}{l}\mathrm{N}- \\
\text { total(\%) }\end{array}$ & $\mathrm{P}_{2} \mathrm{O}_{5}(\%)$ & $\mathrm{K}_{2} \mathrm{O}(\%)$ & $\begin{array}{l}\mathrm{CaO} \\
(\%)\end{array}$ & $\begin{array}{l}\text { MgO } \\
(\%)\end{array}$ & $\mathrm{SO}_{4}(\%)$ \\
\hline 1 & Azolla & 53,76 & 2,62 & 0,80 & 0,62 & - & - & \\
\hline 2 & Kotoran puyuh & 26,37 & 3,08 & 3,25 & 1,44 & - & - & - \\
\hline 3 & $\begin{array}{l}\text { Abu sabut dan } \\
\text { batok kelapa }\end{array}$ & - & - & & 5,83 & - & - & - \\
\hline 4 & Fosfat alam & - & - & 11,26 & & - & - & - \\
\hline 5 & Feldspar & - & - & - & 0,14 & - & - & - \\
\hline 6 & Dolomit & - & - & - & - & 30,98 & 15,86 & \\
\hline
\end{tabular}

- = Tidak dianalisis

Hasil analisis pada Tabel 1 menunjukkan bahwa azolla memiliki C-Organik lebih tinggi $53,76 \%$ dibandingkan dengan kotoran puyuh sebesar $26,37 \%$. $N$ total tertinggi $3,08 \%$ pada kotoran puyuh, sedangkan azolla bernilai $2,62 \%$. Phospat tertinggi pada bahan pupuk fosfat alam yaitu sebesar $11,26 \%$, kemudian pada kototran puyuh sebesar 3,25\%; dan yang terakhir $0,80 \%$ pada azolla. Kalium memiliki nilai tertinggi pada abu sabut dan batok kelapa sebesar $5,83 \%$; kotoran puyuh sebesar $1,44 \%$; azolla $0,62 \%$, dan feldspar $0,14 \%$.pada dolomit memiliki hasil $\mathrm{Ca}$ sebesar 30,98 dan Mg 15,86\%.

Kotoran puyuh memiliki kandungan unsur hara makro $(\mathrm{N}, \mathrm{P}, \mathrm{K})$ yang tinggi dibandingkan bahan pupuk yang lainnya. Salah satu alternatif yang dapat digunakan sebagai sumber pupuk organic yang potensial adalah kotoran puyuh. Karena kotoran puyuh merupakan limbah yang mudah diperoleh dan memiliki kandungan unsur hara yang tinggi karena antara kotoran padat dan cair dapat menyatu. Sehingga dengan penggunaan pupuk kandang puyuh dapat 
menekan penggunaan pupuk anorganik yang dapat merusak lingkungan (Widijanto et al. 2011). Formula Pupuk

Tabel 2. Hasil analisis formula pupuk alam

\begin{tabular}{ccccccccc}
\hline No & Ko d e & C.org & BO & N & P total & K total & Ca & Mg \\
\hline & & $\%$ & $\%$ & $\%$ & $\%$ & $\%$ & $\%$ & $\%$ \\
1 & Formula1 & 13.56 & 23.38 & 1.69 & 6.80 & 2.14 & 6.36 & 0.39 \\
2 & Formula 2 & 23.17 & 39.95 & 1.93 & 8.22 & 2.27 & 8.20 & 0.44 \\
3 & Formula 3 & 28.46 & 49.07 & 2.85 & 1.78 & 2.89 & 0.89 & 0.18 \\
4 & Formula 4 & 39.62 & 68.30 & 2.77 & 3.38 & 2.51 & 1.09 & 0.22 \\
5 & Formula 5 & 40.19 & 69.30 & 2.58 & 4.37 & 3.04 & 1.24 & 0.25 \\
\hline
\end{tabular}

Berdasarkan hasil analisis Formula pupuk, diperoleh hasil yang beragam. Pada C-organik memiliki nilai tertinggi pada Formula $5(40,19 \%)$, BO tertinggi pada Formula 5 (69,30\%), N tertinggi pada Formula $3(2,85 \%), \mathrm{P}$ total tertinggi pada Formula 2 (8.22\%), $\mathrm{K}$ tertinggi pada Formula $5(3,04 \%)$, Ca tertinggi Formula 1 $(6,36 \%)$, dan $\mathrm{Mg}$ tertinggi pada Formula 2 $(0,44 \%)$.

Pupuk organik memegang peranan penting dalam sistem usahatani, karena kemampuannya dalam memperbaiki sifat fisika, kimia, dan biologi tanah. Penggunaan bahan-bahan organik akan menyehatkan tanah, menurunkan tingkat polusi, dan limbah berbahaya sehingga tanah terlindung dari proses degradasi (Widyarti 2009). Respon tanaman terhadap pupuk organik ini umumnya

\section{Variabel Pengamatan}

1. Berat segar brangkasan

Berat segar tanaman mencerminkan serapan unsur hara oleh tanaman.

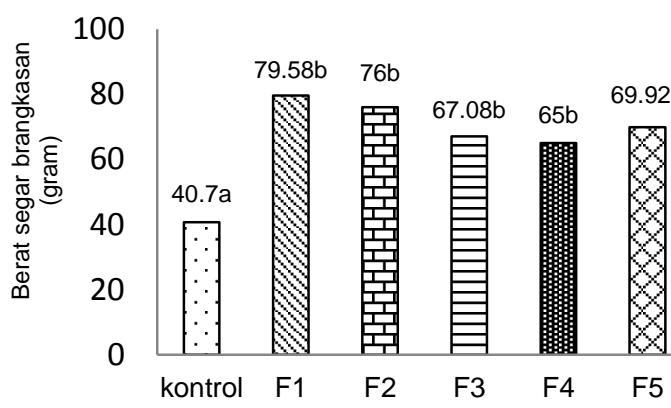

Keterangan:

a. $\mathrm{F} 1=$ Formula $1, \mathrm{~F} 2=$ Formula 2, F3 $=$ Formula $3, F 4=$ Formula 4 , F5 = Formula 5

b. Nilai yang diikuti huruf yang berbeda menunjukkan berbeda nyata pada DMRT taraf $5 \%(P<0,05)$

lambat karena proses penyediaan hara bertahap melalui proses dekomposisi. Namun demikian, pemberian pupuk organik mampu mengefisienkan penggunaan pupuk anorganik dan meningkatkan produksi sebesar $16-36 \%$ (Widowati 2009)

Menurut Barbarick (2006) pupuk organik tidak mengandung unsur hara dalam jumlah yang besar namun penambahan bahan organik ke dalam tanah dapat berpengaruh positif terhadap defisiensi nitrogen pada tanaman. Dengan berkurangnya defisiensi nitrogen, maka serapan nitrogen akan lebih efektif, sehingga kebutuhan nitrogen pada fase vegetatif akan tercukupi dan hasil tanaman sawi akan meningkat. Pemberian pupuk organik juga diharapkan dapat meningkatkan kadar bahan organik tanah

Gambar $\begin{gathered}1 . \quad \begin{array}{c}\text { Pengaruh } \\ \text { terhadap } \\ \text { brangkasan }\end{array} \\ \text { berat }\end{gathered}$

Gambar 1 menunjukkan bahwa pemberian Formula pupuk F1 mengasilkan berat segar tertinggi (79,58 gram), sedangkan yang terendah yaitu Kontrol (40,7 gram). Perbandingan Formula 1 yaitu kotoran puyuh $50 \%$, fosfat alam $20 \%$, abu batok dan sabut kelapa 18\%, dolomit $6 \%$, belerang erlenmentar $1 \%$, dan feldspar $5 \%$.

Berat segar tanaman mencerminkan serapan unsur hara oleh tanaman. Cahyono (2003) mengatakan bahwa sawi merupakan tanaman semusim, pertumbuhannya sangat tanggap terhadap pemupukan. Unsur hara yang diserap tanaman seperti unsur nitrogen yang dibutuhkan oleh tanaman akan membentuk asam amino, meningkatkan protein dan klorofil dan memperbesar sel untuk mempercepat pertumbuhan tanaman sehingga berat dan volume tanaman bertambah.

Serapan Nitrogen yang meningkat menyebabkan kebutuhan Nitrogen pada fase vegetatif tanaman akan tercukupi, sehingga akan 
meningkatkan biomasa tanaman (Irwan et al 2005).

2. Berat Kering Brangkasan

Bahan kering tanaman merupakan gambaran dari translokasi hasil fotosintesis ke seluruh bagian tanaman (Pangaribuan 2010).

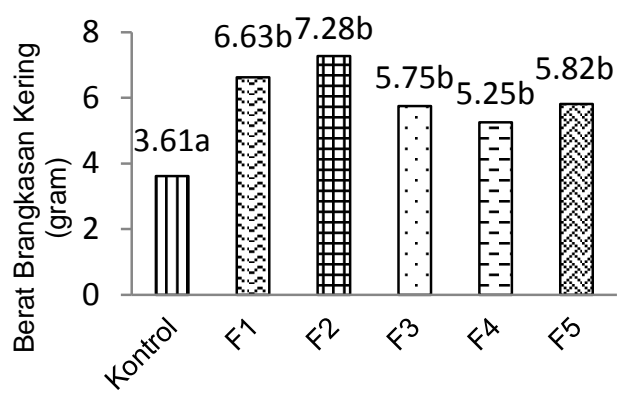

Keterangan:

a. $\mathrm{F} 1=$ Formula $1, \mathrm{~F} 2=$ Formula 2, $\mathrm{F} 3=$ Formula $3, \mathrm{~F} 4=$ Formula 4 , $\mathrm{F} 5=$ Formula 5

b. Nilai yang diikuti huruf yang berbeda menunjukkan berbeda nyata pada DMRT taraf $5 \%(P<0,05)$

3. $\mathrm{N}$ total tanah

Tabel 3. Pengaruh Formula dan dosis pupuk alam terhadap $\mathrm{N}$ tanah

\begin{tabular}{|c|c|c|c|c|c|c|}
\hline & $\mathrm{F} 1$ & F2 & F3 & $\mathrm{F} 4$ & F5 & $\begin{array}{c}\text { Rata- } \\
\text { rata }\end{array}$ \\
\hline D1 & $0.24 a b$ & $0.28 \mathrm{bcde}$ & 0.32 defg & 0.39hi & $0.26 a b c d$ & 0.29 \\
\hline D2 & $0.27 \mathrm{abcd}$ & $0.32 \mathrm{cdefg}$ & $0.31 \mathrm{cde}$ & $0.37 \mathrm{ghi}$ & 0.40hi & 0.33 \\
\hline D3 & $0.21 \mathrm{a}$ & 0.39hi & 0.31 cdef & $0.43 i$ & $0.27 \mathrm{abcd}$ & 0.32 \\
\hline D4 & $0.27 \mathrm{abcd}$ & $0.37 f g h$ & $0.28 \mathrm{bcd}$ & 0.35 efgh & $0.26 \mathrm{abc}$ & 0.30 \\
\hline $\begin{array}{c}\text { Rata- } \\
\text { rata }\end{array}$ & 0.24 & 0.33 & 0.30 & 0.38 & 0.29 & \\
\hline
\end{tabular}

Keterangan:

a. $\mathrm{F} 1=$ Formula 1, F2 = Formula 2, F3 = Formula $3, \mathrm{~F} 4=$ Formula $4, \mathrm{~F} 5=$ Formula 5

b. $\quad \mathrm{D} 1=$ Dosis $1, \mathrm{D} 2=$ Dosis $2, \mathrm{D} 3=$ Dosis 3 D4 = Dosis 4

c. Nilai yang diikuti huruf yang berbeda menunjukkan berbeda nyata pada

DMRT taraf 5\%

Berdasarkan tabel diatas dapat dilihat bahwa pemberian pupuk alam berkadar hara tinggi mempengaruhi $\mathrm{N}$ total tanah. Nilai $\mathrm{N}$ total tanah tertinggi sebesar 0,4267 pada Formula 4 dosis 3. F4D3 terdiri dari komposisi berupa kotoran puyuh $26 \%$, azolla $25 \%$, fosfat alam $20 \%$, abu batok dan sabut kelapa $18 \%$, dolomit $10 \%$, belerang erlenmentar $1 \%$ dengan dosis 3 yaitu 7.500 $\mathrm{kg} / \mathrm{ha}$ dan nilai terendah pada kontrol $0,23 \%$. Kandungan $\mathrm{N}$-total tanah yang rendah pada awal percobaan menyebabkan pemberian pupuk $\mathrm{N}$ berpengaruh sangat nyata terhadap kandungan $\mathrm{N}$-total tanah.
Gambar 2. Pengaruh Formula pupuk alam terhadap berat kering brangkasan

Berat brangkasan kering pada gambar 3 menunjukkan bahwa pemberian Formula pupuk F2 mengasilkan berat kering dengan rata-rata berat sebesar 10,28 gram, perbandingan Formula 2 yaitu kotoran puyuh $60 \%$, fosfat alam $20 \%$, abu batok dan sabut kelapa $14 \%$, dolomit $5,5 \%$, belerang erlenmentar $0,5 \%$. Sedangkan yang terendah yaitu Kontrol/D0 sebesar 4,45 gram. Hasil berat kering merupakan keseimbangan antara fotosintesis dan respirasi. Fotosintesis mengakibatkan peningkatan berat kering tanaman karena pengambilan $\mathrm{CO} 2$ sedangkan respirasi mengakibatkan penurunan berat kering karena pengeluaran $\mathrm{CO} 2$ (Gardner dkk.,1991 cit Giyatmi et al. 2008).
Peningkatan $\mathrm{N}$ total tanah disebabkan oleh adanya sumbangan nitrogen yang bersumber dari senyawa organik dan menghasilkan asam-asam organik. Apabila asam-asam amino mengalami hidrolisis akan menghasilkan ammonium $\left(\mathrm{NH}_{4}{ }^{+}\right)$atau nitrat $\left(\mathrm{NO}_{3}{ }^{-}\right)$yang tersedia bagi tanaman (Isrun 2009). 
4. Serapan N

Tabel 4. Pengaruh Formula dan dosis pupuk alam terhadap serapan $\mathrm{N}$

\begin{tabular}{lccclcc}
\hline & F1 & F2 & \multicolumn{1}{c}{ F3 } & F4 & F5 & $\begin{array}{c}\text { Rata- } \\
\text { rata }\end{array}$ \\
\hline D1 & $20.28 \mathrm{bcdef}$ & $18.29 \mathrm{bc}$ & $20.33 \mathrm{bcdef}$ & $15.33 \mathrm{ab}$ & $20.96 \mathrm{bcdef}$ & 19.04 \\
D2 & $19.71 \mathrm{bcde}$ & $22.28 \mathrm{bcdef}$ & $18.48 \mathrm{bc}$ & $27.31 \mathrm{f}$ & $21.55 \mathrm{bcdef}$ & 21.86 \\
D3 & $21.64 \mathrm{bcdef}$ & $26.73 \mathrm{ef}$ & $23.56 \mathrm{cdef}$ & $19.68 \mathrm{bcde}$ & $18.70 \mathrm{bcd}$ & 22.06 \\
D4 & 26.80 & $26.14 \mathrm{def}$ & $19.30 \mathrm{bcde}$ & $22.16 \mathrm{bcdef}$ & $\mathbf{3 6 . 9 1 f}$ & 26.26 \\
Rata- & 22.11 & 23.36 & 20.4175 & 21.12 & 24.53 & \\
rata & & & & & & \\
\hline
\end{tabular}

Keterangan:
a. $\mathrm{F} 1=$ Formula $1, \mathrm{~F} 2=$ Formula $2, \mathrm{~F} 3=$ Formula $3, \mathrm{~F} 4=$ Formula $4, \mathrm{~F} 5=$ Formula 5
b. $\quad \mathrm{D} 1=$ Dosis $1, \mathrm{D} 2=$ Dosis $2, \mathrm{D} 3=$ Dosis $3 \mathrm{D} 4$ = Dosis 4
c. Nilai yang diikuti huruf yang berbeda menunjukkan berbeda nyata pada DMRT taraf $5 \%(P<0,05)$

Dari Tabel diatas dapat dilihat bahwa hasil uji $\mathrm{N}$ jaringan tanaman berbeda nyata antar formula dan dosis, sehingga pemberian pupuk alam berkadar hara tinggi mempengaruhi serapan $\mathrm{N}$ jaringan tanaman. Nilai serapan $\mathrm{N}$ tertinggi sebesar 3,0367 pada Formula 3 dosis 1 . F3D1 terdiri dari komposisi berupa kotoran puyuh $20 \%$, azolla $30 \%$, fosfat alam $16 \%$, abu batok dan sabut kelapa $23 \%$, dolomit $10 \%$, belerang erlenmentar $1 \%$ dengan dosis 1 yaitu 2.500 $\mathrm{kg} / \mathrm{ha}$.

Formula pupuk yang berbeda akan menjadikan ketersediaan $\mathrm{N}$ yang berbeda pula bagi tanaman pada masa awal pertumbuhan. Jarak tanam juga berperan dalan peningkatan penyerapan hara $\mathrm{N}$ oleh tanaman karena semakin lebar jarak tanam semakin luas area perakaran, sehingga persaingan untuk mendapatkan hara antara tanaman satu dengan yang lain akan semakin berkurang. Pemberian pupuk organik dapat meningkatkan efisiensi serapan Nitrogen pada tanaman (Barbarick 2006).

\section{KESIMPULAN DAN SARAN}

\section{Kesimpulan}

Kesimpulan yang dapat ditarik dari penelitian ini adalah sebagai berikut:

1. Berat segar brangkasan dengan penambahan pupuk alam mendapatkan nilai tertinggi 79,58 gram pada formula 1 dengan perbandingan kotoran puyuh 50\%, fosfat alam $20 \%$, abu batok dan sabut kelapa $18 \%$, dolomit $6 \%$, belerang erlenmentar $1 \%$, dan feldspar $5 \%$. Sedangkan Berat kering brangkasan dengan rata-rata berat sebesar 10,28 gram pada formula 2, perbandingan komposisi formula 2 yaitu kotoran puyuh
$60 \%$, fosfat alam $20 \%$, abu batok dan sabut kelapa $14 \%$, dolomit $5,5 \%$, belerang erlenmentar $0,5 \%$.

2. Pemberian pupuk alam berpengaruh nyata terhadap serapan $\mathrm{N}$ tertinggi sebesar 3,03 pada Formula 3 dosis 1 F3D1 terdiri dari komposisi berupa kotoran puyuh $20 \%$, azolla $30 \%$, fosfat alam $16 \%$, abu batok dan sabut kelapa $23 \%$, dolomit $10 \%$, belerang erlenmenter $1 \%$ dengan dosis 1 yaitu 2.500 $\mathrm{kg} / \mathrm{ha}$.

\section{Saran}

Saran yang diberikan untuk penelitian ini adalah perlu dilakukannya penelitian lanjutan tentang penggunaan pupuk alam terhadap tanaman lainnya, dan perlu adanya kombinasi komposisi pupuk alam yang digunakan.

\section{DAFTAR PUSTAKA}

Barbarick, KA. 2006, Organic Materials As Nitrogen Fertilizers, Colorado : Colorado State University.

Cahyono, 2003, Budidaya dan Analisis Tani, Jakarta : Kanisius.

Irwan, AW., Wahyudin, A., Farida, 2005, Pengaruh Dosis Kascing dan Bioaktivator Terhadap Pertumbuhan dan Hasil Tanaman Sawi (Brassica juncea L.) Yang Dibudidayakan Secara Organik, Jurnal Kultivasi, 4(2) : $136-140$.

Isrun, 2009, Respons Inceptisols Terhadap Pupuk Guano dan Pupuk P Serta Pengaruhnya Terhadap Serapan $P$ Tanaman Kacang Tanah, J Agroland, 16(1) : 40-44.

Pangaribuan, HD., 2010, Analisis pertumbuhan tomat pada berbagai jenis pupuk kandang, Prosiding seminar nasional sains dan teknologi - III, hal 149-155.

Purwanto, E., Handayanto, Suparyogo, D., Hairiah, K. 2007, Nitrifikasi Potensial dan Nitrogen-Mineral Tanahpada Sistem Agroforestri Kopi dengan Berbagai Spesies Pohon Penaung, Jurnal Pelita Perkebunan, 23 (1).

Ruhnayat, A., 2010, Kebutuhan Unsur Hara Beberapa Tanaman Obat Berimpang dan 
Responnya Terhadap Pemberian Pupuk Organik, Pupuk Bio dan Pupuk Alam, http://balittro.litbang.deptan.go.id, Diakses tanggal 12 Mei 2016.

Widijanto, H., Noviana, A., Suntoro, 2011,

Efisiensi Serapan $S$ dan Hasil Padi Dengan Pemberian Pupuk Kandang Puyuh dan Pupuk Anorganik di Lahan Sawah (Musim Tanam II), Jurnal IImu Tanah dan Agroklimatologi, 8(1) : 61-70.

Widowati, LR. 2009, Peranan Pupuk Organik terhadap Efisiensi Pemupukan dan Tingkat Kebutuhannya untuk Tanaman Sayuran pada Tanah Inseptisols Ciherang, Bogor : Jurnal Tanah Tropika, 14(3) : 221-228.

Widyarti, B. 2009, Hidup Organik, Panduan Ringkas Berperilaku Selaras Alam, Aliansi Organis Indonesia, Bogor, Hal 10. 